\title{
Enzymatic Synthesis Optimization of Isoamyl Butyrate
}

\author{
Andréia Anschau, *Vitor C. Aragão, Barbara D. A. Porciuncula, Susana J. Kalil, \\ Carlos A. V. Burkert and Janaína F. M. Burkert
}

\author{
Escola de Química e Alimentos, Universidade Federal do Rio Grande, CP 474, \\ 96201-900 Rio Grande-RS, Brazil
}

\begin{abstract}
Lipozyme TL IM foi usada para catalisar a esterificação de álcool isoamílico e ácido butírico. Um planejamento fatorial fracionário foi utilizado para avaliar os efeitos da temperatura (30, $\left.40,50{ }^{\circ} \mathrm{C}\right)$, razão molar álcool:ácido $(1: 1,2: 1,3: 1)$, concentração de enzima $(0,003,0,0115$, $\left.0,020 \mathrm{~g} \mathrm{~mL}^{-1}\right)$, concentração de ácido butírico $\left(0,1,0,3,0,5 \mathrm{~mol} \mathrm{~L}^{-1}\right)$ e agitação $(50,115,180 \mathrm{rpm})$ na produção de éster. Com esses resultados, os níveis foram redefinidos para um planejamento fatorial $2^{3}$. A máxima produção de éster foi obtida a $30^{\circ} \mathrm{C}, 180 \mathrm{rpm}$, razão molar álcool:ácido de $1: 1$, concentração de enzima $0,021 \mathrm{~g} \mathrm{~mL}^{-1}$ e concentração de ácido butírico de $0,5 \mathrm{~mol} \mathrm{~L}^{-1}$. Sob essas condições ótimas foi obtido $92 \%$ de esterificação e concentração de éster de 0,9 mol L-1. Álcool isoamílico obtido a partir de óleo fúsel foi utilizado nas mesmas condições resultando em 93\% de esterificação e concentração de éster de $1,0 \mathrm{~mol} \mathrm{~L}^{-1}$.
\end{abstract}

Lipozyme TL IM was used to catalyse the esterification of isoamyl alcohol and butyric acid. A fractional factorial design was employed to evaluate the effects of temperature $\left(30,40,50{ }^{\circ} \mathrm{C}\right)$, alcohol:acid molar ratio $(1: 1,2: 1,3: 1)$, enzyme concentration $\left(0.003,0.0115,0.020 \mathrm{~g} \mathrm{~mL}^{-1}\right)$, butyric acid concentration $\left(0.1,0.3,0.5 \mathrm{~mol} \mathrm{~L}^{-1}\right)$ and shaking rate $(50,115,180 \mathrm{rpm})$ on the ester yield. With these results, the levels were redefined to a $2^{3}$ factorial design. The maximum yield of ester was obtained at $30^{\circ} \mathrm{C}, 180 \mathrm{rpm}$, alcohol:acid molar ratio of 1:1, enzyme concentration of $0.021 \mathrm{~g} \mathrm{~mL}^{-1}$ and butyric acid concentration of $0.5 \mathrm{~mol} \mathrm{~L}^{-1}$. Under the optimal conditions, $92 \%$ esterification was attained with an ester concentration of $0.9 \mathrm{~mol} \mathrm{~L}^{-1}$. Isoamyl alcohol from fusel oil was used under the same conditions and resulted in $93 \%$ esterification and an ester concentration of $1.0 \mathrm{~mol} \mathrm{~L}-1$.

Keywords: flavor ester, Lipozyme TL-IM, organic media, response surface methodology (RSM), fusel oil

\section{Introduction}

Short chain fatty acid and alcohol esters are important components of natural aromas used in the food industry. Currently, most of the flavour and fragrance components are obtained by traditional methods, which include chemical synthesis or extraction from natural sources. The concept of a natural ester made by enzymatic synthesis with lipase and natural substrate components is an attractive alternative to such routes. ${ }^{1}$

Biotechnological processes are more expensive than chemical ones but they have clear environmental advantages, since the use of inorganic acids (employed as catalysts in chemical syntheses) is avoided, and the

*e-mail: andreiaanschau@hotmail.com enzymes (when immobilized) can be reused, therefore, minimizing the reaction residues. The most used reaction media in enzymatic syntheses still are organic solvents such as hexane or heptane, which can be recovered for reuse. ${ }^{2}$

Enzymatic catalysis in organic media allows to obtain pure products, due to enzyme specificity. In addition, the catalysis is carried out under mild reaction conditions, which minimize side reactions when compared to the chemical process. Moreover, enzymatic syntheses can be performed using less toxic or non-toxic solvents as compared to chemical syntheses. ${ }^{3}$ Interest in the use of organic solvents is mainly due to enhancement of the solubility of hydrophobic substrates, the elimination of side reactions caused by water, ease of product recovery and protection from microbial contamination. ${ }^{4}$ 
Lipases (triacylglycerol acylhydrolases; EC 3.1.1.3) are one of the most important classes of hydrolytic enzymes, catalyzing both the hydrolysis and synthesis of esters. Microbial lipases are widely diversified in their properties and substrate specificity, which make them attractive tools for industrial applications. ${ }^{5}$ Lipases display catalytic activity towards a large variety of alcohols and acids in reactions involving ester synthesis. ${ }^{6}$

Response surface methodology (RSM) is an efficient statistical technique for the optimization of multiple variables, in order to predict the best performance conditions with a minimum of experiments, and the optimization of the lipase-catalyzed production of various esters has been investigated by RSM .

In countries where ethanol is produced as a fuel on a large scale, such as Brazil, the use of the by-products has become an important issue to make the production of ethanol less polluting and more profitable. ${ }^{8}$ The fusel oil obtained from the distillation of fermented agricultural products is currently used as a raw material for the production of amyl and butyl alcohols. Fusel oil had been used as foam coating or as fuel for energy source. Also, esters obtained from alcohols of fusel oil can be used industrially as solvents and flavoring, medicinal and plasticizer agents. ${ }^{7}$ However, a great part of the fusel oil produced is generally discarded. ${ }^{9}$ Its average composition is $51 \% i$-amyl-alcohol, $15 \% i$-butanol, $13 \% n$-propanol, $10 \%$ ethanol, $11 \%$ miscellaneous alcohols and water. ${ }^{10}$

Here, we wish to report a study employing isoamyl alcohol from fusel oil instead of pure isoamyl alcohol. The present work focused on the reaction parameters that affect the use of Lipozyme TL IM in the esterification of isoamyl alcohol and butyric acid with $n$-hexane as the organic solvent. The main objectives of this work were to develop an approach that would enable a better understanding of the relationships between the variables (temperature, concentrations of enzyme and butyric acid, alcohol: acid molar ratio and the rate of shaking) and the responses (percent esterification and ester concentration), to obtain the optimum conditions for the synthesis of isoamyl butyrate using a central composite rotatable design (CCRD) and RSM analysis, and to compare the results obtained under the optimum conditions, using commercial isoamyl alcohol and isoamyl alcohol obtained from fusel oil, in order to use this by-product in future studies.

\section{Experimental}

\section{Enzyme}

The biocatalyst employed was the commercial microbial lipase Lipozyme TL IM $\left(53.1 \mathrm{Ug}^{-1}\right)$, immobilized on silica and provided by Novozymes (Bagsvaerd, Denmark). It is produced by genetically modified Aspergillus oryzae, under submerged fermentation. The microbial donor of the gene that expresses the lipase production is Thermomyces lanuginosus.

\section{Chemicals}

All chemicals were of analytical grade. The fusel oil (Sugarcane Technology Centre- CTC, Piracicaba-SP, Brazil) was distilled in order to obtain the isoamyl alcohol, which was used in the synthesis. Fractions above the boiling point of $120^{\circ} \mathrm{C}$ (rich in isoamyl alcohol, its boiling temperature is $128^{\circ} \mathrm{C}$ ) were collected and distilled again. Isoamyl alcohol obtained by distillation at purity of $97.6 \%$ $(\mathrm{v} / \mathrm{v})$ was used in esterification.

\section{Ester synthesis}

In previous study, Aragão et al., ${ }^{11}$ tested different solvents, such as acetone, chloroform, toluene, hexane and heptanes, which have $\log \mathrm{P}$ values of $-0.23,2,2.5,3.5$ and 4.0, respectively. The organic solvents, $n$-hexane and $n$-heptane, with similar chemical nature presented similar results, reaching a conversion of 80.1 and $84.5 \%$ at $48 \mathrm{~h}$, respectively. Based on RDC No. 2, from ANVISA, ${ }^{12}$ the use of solvents is allowed in the preparation of flavouring in prescribed quantities, among which acetone, $n$-hexane and toluene are allowed in small concentrations. However, $n$-hexane can be used for food applications, ${ }^{13}$ and was selected for further studies to optimize the reaction parameters on isoamyl butyrate synthesis.

Synthesis of the ester was carried out in a $100 \mathrm{~mL}$ stoppered flask, with a working volume of $40 \mathrm{~mL}$ of $n$-hexane, containing glass beads and the required concentrations of isoamyl alcohol and butyric acid according to the experimental designs. An appropriate enzyme concentration was added to the freshly prepared reaction mixture, which was incubated in an orbital shaking incubator (Tecnal TE-420) at $180 \mathrm{rpm}$ at the specified temperatures.

\section{Determination of the percent esterification}

Aliquots of the reaction mixture were withdrawn at definite time intervals ( $3 \mathrm{~h}, 6 \mathrm{~h}, 18 \mathrm{~h}, 24 \mathrm{~h}$ and $48 \mathrm{~h}$ ) and the extent of esterification monitored by a titration procedure to estimate the decrease in total acid content of the reaction mixture. Titration was carried out using $0.02 \mathrm{~mol} \mathrm{~L}^{-1}$ standard potassium hydroxide with phenolphthalein as the indicator ${ }^{14,15}$ and $3 \mathrm{~mL}$ of ethanol used as the quenching 
agent to determine the residual acid content. ${ }^{2}$ The percent esterification was calculated from the concentration of acid consumed in the reaction mixture, determined from the values obtained in the titration for both the blank and the test sample, ${ }^{16}$ using equation 1 :

$\operatorname{molar} \%=\frac{\mathrm{C}_{0}-\mathrm{C}}{\mathrm{C}_{0}} \times 100$

where: $\mathrm{C}_{0}=$ concentration of free fatty acid residues at $0 \mathrm{~h}$; $\mathrm{C}=$ concentration of free fatty acid residues after time $\mathrm{t}$.

\section{Determination of ester concentration}

Ester concentration was defined as the ratio of ester amount (mmol) to total amount of substrates (grams of isoamyl alcohol plus grams butyric acid), [mmol ester . gram $\left._{\text {mixture }}\right],{ }^{17}$ and converted to $\mathrm{mol} \mathrm{L}^{-1}$.

\section{Experimental design and optimization by RSM}

The influence of various reaction parameters such as temperature, enzyme concentration, butyric acid concentration, alcohol:acid molar ratio and shaking rate in the synthesis using Lipozyme TL IM, was evaluated using a $2_{\mathrm{v}}^{5-1}$ fractional factorial design, ${ }^{18}$ with central points, giving a total of 20 trials, to study the percent esterification and ester concentration (Table 1).

According to the results of the first factorial design, a second experimental design was used to identify the optimum levels of the parameters for the synthesis of isoamyl butyrate (Table 2). A $2^{3}$ central composite rotatable design (CCRD) with a star configuration ( 2 axial points) and 4 central points, giving a total of 18 trials, was used to obtain a second order model. The distance of the axial points was \pm 1.68 as calculated from equation $2 .{ }^{19}$

$\alpha=\left(2^{n}\right)^{1 / 4}$

where $\alpha$ is the distance of the axial points and $n$ is the number of independent variables.

The variables studied in the CCRD were temperature $\left(30-50{ }^{\circ} \mathrm{C}\right)$, substrate concentration $\left(0.1-0.9 \mathrm{~mol} \mathrm{~L}^{-1}\right)$ and enzyme concentration (0.005-0.025 $\left.\mathrm{g} \mathrm{mL}^{-1}\right)$.

RSM is used in the empirical study of relationships between one or more measured responses and a number of input variables, and the objective is to optimize the response(s). It offers solutions to critical questions such as how a particular response is affected by a given set of input variables over some specified region of interest, what settings of factors will give a product simultaneously satisfying desired specifications, and which values (within the range) of the factors will yield a maximum for a specific response. ${ }^{7}$ A quadratic response surface model was fitted to equation 3.

$\mathrm{Y}=\beta_{0}+\Sigma \beta_{\mathrm{i}} \mathrm{x}_{\mathrm{i}}+\Sigma \beta_{\mathrm{ii}} \mathrm{x}^{2}+\Sigma \beta_{\mathrm{ii}} \mathrm{x}_{\mathrm{i}} \mathrm{x}_{\mathrm{ij}}+\varepsilon$

where $\mathrm{Y}$ is the dependent variable (response variable) to be modelled, $x_{i}$ and $x_{j}$ are the independent variables (factors), $\beta_{0}, \beta_{\mathrm{i}}, \beta_{\mathrm{ii}}$ and $\beta_{\mathrm{ij}}$ are the regression coefficients of the model and $\varepsilon$ is the error of the model (residual term). Where possible, the model was simplified by dropping terms which were not statistically significant ( $p>0.05$ ) according to the analysis of variance..$^{20}$ The value for $\mathrm{R}^{2}$ indicates the percent of the variability in the optimization parameter that is explained by the model. Three-dimensional surface plots were drawn to illustrate the main and interactive effects of the independent variables on the dependent ones. ${ }^{6}$

\section{Statistical analysis}

All the data were analysed with the aid of Statistica 7.0 (Statsoft, Inc., Tulsa, OK, USA).

\section{Results and Discussion}

\section{$2_{v}^{5-1}$ Fractional factorial design}

Effect of the reaction parameters on the percent esterification

Monitoring of the enzymatic synthesis was carried out for $48 \mathrm{~h}$. However, after $18 \mathrm{~h}$ there was no significant increase for most of the trials, and therefore this time was chosen to analyse the effect of the reaction parameters on the responses. The maximum percent esterification after $18 \mathrm{~h}$ of reaction was $94.0 \%$ (Table 1) for trial 14 at $50{ }^{\circ} \mathrm{C}$, with $0.1 \mathrm{~mol} \mathrm{~L}^{-1}$ butyric acid, a concentration of $0.020 \mathrm{~g} \mathrm{~mL}^{-1}$ of Lipozyme TL IM, an alcohol:acid molar ratio of 3:1 and a shaking rate of $180 \mathrm{rpm}$.

In a previous study, Aragão et al., ${ }^{11}$ investigated the isoamyl butyrate production using free and immobilized lipases by esterification of butyric acid with isoamyl alcohol in a solvent-free system and in an organic media. Among the studied enzymes, Lipozyme TL IM was found to be the most active catalyst in $n$-hexane as a solvent. The effects of different solvents and the amount of water added on conversion rates were studied. A maximum conversion yield of $80 \%$ in $n$-hexane at $48 \mathrm{~h}$ was obtained under the following fixed conditions: $0.003 \mathrm{~g} \mathrm{~mL}^{-1}$ of Lipozyme TL IM, $30^{\circ} \mathrm{C}, 180 \mathrm{rpm}$, alcohol:acid molar ratio of $1: 1$ and $0.6 \mathrm{~mol} \mathrm{~L}^{-1}$ butyric acid. 
In trial 4 the responses were very low during the reaction time, reaching $0 \%$ after $18 \mathrm{~h}$. This may have occurred because of reversibility (hydrolysis) when using such a low enzyme concentration $\left(0.003 \mathrm{~g} \mathrm{~mL}^{-1}\right)$ or also due to the high acid concentration $\left(0.5 \mathrm{~mol} \mathrm{~L}^{-1}\right)$ as well as in trials 3 and 11 . Macedo et al., ${ }^{21}$ obtained similar results for the synthesis of isoamyl butyrate when it was used an alcohol:acid molar ratio of 4:1 and only $1 \%$ of lipase from Geotrichum $s p$. Using these parameters the authors obtained about $7 \%$ conversion in $72 \mathrm{~h}$. However, using the same molar ratio and an enzyme concentration of $10 \%$, the conversion reached $50 \%$ in $72 \mathrm{~h}$.

In trial 11, with low enzyme concentration $\left(0.003 \mathrm{~g} \mathrm{~mL}^{-1}\right)$, high acid concentration $\left(0.5 \mathrm{~mol} \mathrm{~L}^{-1}\right)$ and high alcohol:acid molar ratio (3:1), the maximum esterification of $69.6 \%$ was obtained after $6 \mathrm{~h}$ then decreased, reaching to $0 \%$ at the end of the trial $(18 \mathrm{~h})$. It may be that around the critical molar ratio, competitive alcohol binding reduces formation of the acyl-enzyme complex, resulting in a decrease in alcoholysis. This observation may also reflect the ability of excess alcohol to distort the essential water layer from around the enzyme molecules. ${ }^{22}$

The entire relationship between the reaction factors and the response can be understood better by examining
Figure 1a, where increasing the reaction temperature, enzyme concentration and shaking rate from their lowest levels to their highest levels had a positive effect on synthesis, increasing, on average by $19 \%, 42 \%$ and $12 \%$ at $18 \mathrm{~h}$, respectively.

The opposite occurred with the isoamyl alcohol:butyric acid molar ratio and the butyric acid concentration, both of which had a negative effect, causing a decrease of, on average, $8 \%$ and $38 \%$ at $18 \mathrm{~h}$, respectively. The negative effect of the butyric acid concentration indicates the importance of working at low levels of acid and alcohol.

\section{Effect of the reaction parameters on the ester concentration}

From the monitoring of the synthesis, the highest isoamyl butyrate concentration of $1.4 \mathrm{~mol} \mathrm{~L}^{-1}$ was shown to occur at $18 \mathrm{~h}$ in trial 8 (Table 1). The parameters temperature, enzyme concentration and butyric acid concentration exerted a positive effect on the synthesis of isoamyl butyrate as they increased from their lower levels to their highest levels (Figure 1b). The molar ratio had a small negative effect and an increase in shaking rate showed no significant influence $(p>0.05)$.

Table 1. ${ }^{5-1}$ Fractional factorial design with the real values for the variables and the percent esterification and ester concentration after $18 \mathrm{~h}$

\begin{tabular}{|c|c|c|c|c|c|c|c|}
\hline \multirow{2}{*}{ Trial } & \multicolumn{5}{|c|}{ Variables } & \multicolumn{2}{|c|}{ Responses } \\
\hline & $\mathrm{T} /{ }^{\circ} \mathrm{C}$ & $\mathrm{S} /\left(\mathrm{mol} \mathrm{L}^{-1}\right)$ & $\mathrm{E} /\left(\mathrm{g} \mathrm{mL}^{-1}\right)$ & Alcohol:acid molar ratio & $\mathrm{V} / \mathrm{rpm}$ & PE & EC \\
\hline 1 & 30 & 0.1 & 0.003 & $1: 1$ & 180 & 85.7 & 0.2 \\
\hline 2 & 50 & 0.1 & 0.003 & $1: 1$ & 50 & 84.8 & 0.3 \\
\hline 3 & 30 & 0.5 & 0.003 & $1: 1$ & 50 & 3.2 & 0.0 \\
\hline 4 & 50 & 0.5 & 0.003 & $1: 1$ & 180 & 0.0 & 0.0 \\
\hline 5 & 30 & 0.1 & 0.020 & $1: 1$ & 50 & 78.1 & 0.2 \\
\hline 6 & 50 & 0.1 & 0.020 & $1: 1$ & 180 & 83.2 & 0.2 \\
\hline 7 & 30 & 0.5 & 0.020 & $1: 1$ & 180 & 89.5 & 1.0 \\
\hline 8 & 50 & 0.5 & 0.020 & $1: 1$ & 50 & 91.8 & 1.4 \\
\hline 9 & 30 & 0.1 & 0.003 & $3: 1$ & 50 & 30.1 & 0.1 \\
\hline 10 & 50 & 0.1 & 0.003 & $3: 1$ & 180 & 87.9 & 0.2 \\
\hline 11 & 30 & 0.5 & 0.003 & $3: 1$ & 180 & 0.0 & 0.0 \\
\hline 12 & 50 & 0.5 & 0.003 & $3: 1$ & 50 & 26.4 & 0.4 \\
\hline 13 & 30 & 0.1 & 0.020 & $3: 1$ & 180 & 93.4 & 0.3 \\
\hline 14 & 50 & 0.1 & 0.020 & $3: 1$ & 50 & 94.0 & 0.3 \\
\hline 15 & 30 & 0.5 & 0.020 & $3: 1$ & 50 & 28.3 & 0.4 \\
\hline 16 & 50 & 0.5 & 0.020 & $3: 1$ & 180 & 92.3 & 1.1 \\
\hline 17 & 40 & 0.3 & 0.0115 & $2: 1$ & 115 & 31.8 & 0.2 \\
\hline 18 & 40 & 0.3 & 0.0115 & $2: 1$ & 115 & 29.5 & 0.2 \\
\hline 19 & 40 & 0.3 & 0.0115 & $2: 1$ & 115 & 30.7 & 0.2 \\
\hline 20 & 40 & 0.3 & 0.0115 & $2: 1$ & 115 & 32.6 & 0.2 \\
\hline
\end{tabular}

$\mathrm{PE}=$ percent esterification $(\%) ; \mathrm{EC}=$ ester concentration $\left(\mathrm{mol} \mathrm{L}^{-1}\right)$. 
(a)

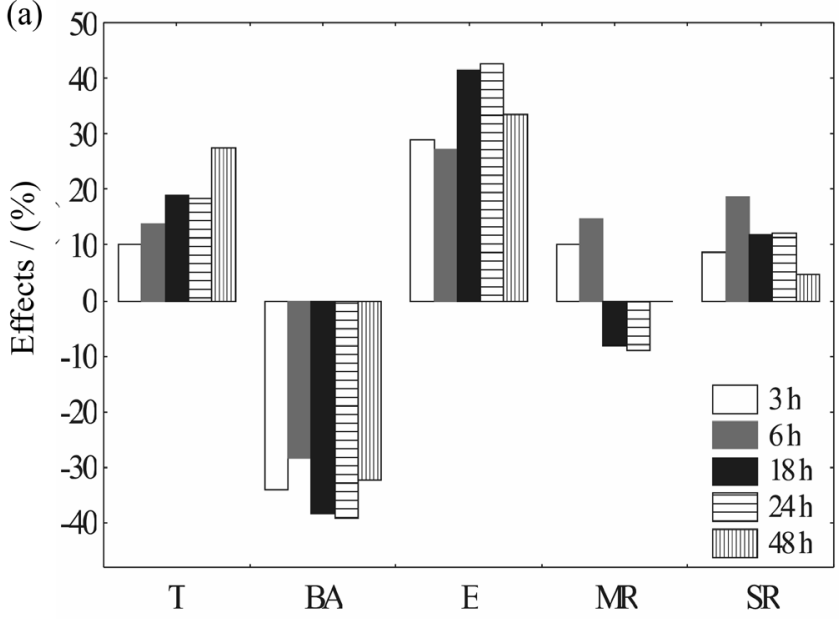

(b)

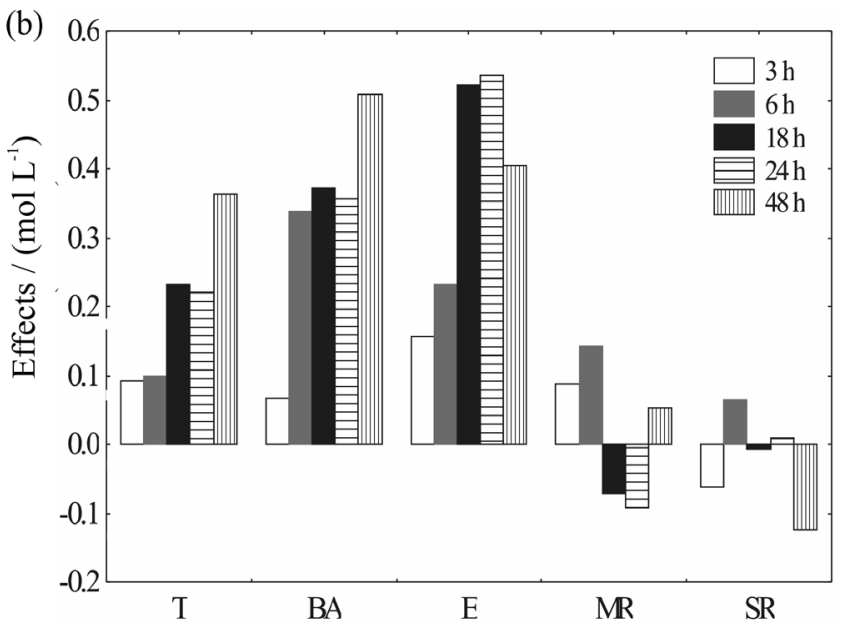

Figure 1. Effects of the reaction parameters on (a) percent esterification and (b) ester concentration in the synthesis of isoamyl butyrate. T: temperature; BA: butyric acid concentration; E: enzyme concentration; MR: alcohol: acid molar ratio; SR: shaking rate.

Similar results were obtained by Güvenç et al.,${ }^{17}$ who studied the effect of enzyme concentration. An increase in the enzyme concentration from 2.5 to $10 \%(\mathrm{~m} / \mathrm{m})$ resulted in an increase from 0.7 to $3.2 \mathrm{~mol} \mathrm{~L}^{-1}$ in the synthesis of isoamyl acetate when the lipase Novozymes 435 was used in a solvent-free system, showing that the effect of enzyme concentration is important in the synthesis.

The variables temperature, enzyme concentration and butyric acid concentration were selected and studied using a CCRD (Table 2). Despite the positive effect of increasing the temperature level, this parameter was maintained at the same level, due to the risk of enzyme denaturation. The enzyme and butyric acid concentration levels were expanded due to the positive effects shown.

The isoamyl alcohol:butyric acid molar ratio was fixed at 1:1 (level-1) in the CCRD, since the change from 1:1 to 3:1 showed a negative effect, reducing esterification to $8 \%$. Although an increase in the shaking rate resulted in a greater percent esterification, its variation was not statistically significant for the ester concentration, and therefore it was set at $180 \mathrm{rpm}($ level +1$)$.

\section{Model fitting}

\section{$2^{3}$ Central composite rotatable design (CCRD)}

Response surface methodology consists of an empirical modelization technique, which can be used to evaluate the relationship between experimental and observed results. In order to determine whether the quadratic model is significant or not, it is necessary to carry out an regression analysis and variance (ANOVA) using the usual Fisher $F$-tests, in which the sum of squares in the regression is subdivided into two parts that attributed to linear regression and that attributed to the quadratic model. ${ }^{7}$
After $18 \mathrm{~h}$ of reaction time there was no significant increase in the percent esterification and ester concentration in most of the trials, and, therefore, this time was chosen to optimize the synthesis. Table 2 shows the variables in real values, percent esterification, ester concentration and values predicted by the model, plus their standard deviations.

The ANOVA (Table 3) indicated that the model was significant and adequate to represent the current relationship between the responses and the significant variables, showing a very small $p$-value $(0.05)$ and a satisfactory coefficient of determination ( $p$-values below 0.05 indicate that the terms of the model are significant)..$^{22}$

The pure error was very low, indicating good reproducibility of the data obtained. The Fisher $F$-test also demonstrated very high significance for the regression model, since the $F$-value computed (30.98) was much higher than the tabulated $F$-value (3.39) for the percent esterification at the 5\% level. The coefficient of determination $\left(\mathrm{R}^{2}\right)$ was 0.972 , which indicates that only $2.8 \%$ of the overall variation was not explained by the model. Thus the model adequately represented the real relationships between the selected parameters, and similar results were obtained for ester concentration. From the analysis of variance (Table 3 ), the coefficient of correlation obtained for the percent esterification and the result of the $F$-test $\left(9.1\right.$ times higher than $\mathrm{F}_{\text {tab }}$ ) were good indicators of a representative model of the current relationship amongst the selected reaction parameters (equation 4).

For the ester concentration, the correlation coefficient obtained was 0.926 and the ratio of $\mathrm{F}_{\text {calc }} / \mathrm{F}_{\text {tab }}$ was 3.27, indicating that the second order model was also statistically significant and predictive (equation 5).

According to the $t$ and $p$ values from regression analysis, all the variables have statistical significance on the percent 
Table 2. $2^{3}$ Factorial design with the real values for the variables and the percent esterification and ester concentration after $18 \mathrm{~h}$ plus the values predicted by the model and the standard deviations

\begin{tabular}{|c|c|c|c|c|c|c|c|c|c|}
\hline \multirow[t]{2}{*}{ Trial } & \multicolumn{3}{|c|}{ Variables } & \multicolumn{3}{|c|}{$\begin{array}{c}\text { Response value for percent } \\
\text { esterification / }(\%)\end{array}$} & \multicolumn{3}{|c|}{$\begin{array}{l}\text { Response value for ester } \\
\text { concentration } /\left(\mathrm{mol} \mathrm{L}^{-1}\right)\end{array}$} \\
\hline & $\mathrm{T} /{ }^{\circ} \mathrm{C}$ & $\mathrm{S} /\left(\mathrm{mol} \mathrm{L}^{-1}\right)$ & $\mathrm{E} /\left(\mathrm{g} \mathrm{mL}^{-1}\right)$ & $\mathrm{PE}$ & $\mathrm{PV}$ & $\mathrm{SD}$ & $\mathrm{EC}$ & $\mathrm{PV}$ & $\mathrm{SD}$ \\
\hline 1 & 34 & 0.26 & 0.009 & 90.2 & 84.9 & 5.9 & 0.5 & 0.6 & 17.6 \\
\hline 2 & 46 & 0.26 & 0.009 & 88.3 & 84.7 & 4.1 & 0.5 & 0.5 & 8.8 \\
\hline 3 & 34 & 0.74 & 0.009 & 16.6 & 15.5 & 6.7 & 0.3 & 0.2 & 8.2 \\
\hline 4 & 46 & 0.74 & 0.009 & 35.8 & 26.5 & 26.0 & 0.6 & 0.5 & 17.2 \\
\hline 5 & 34 & 0.26 & 0.021 & 90.4 & 93.8 & 3.7 & 0.5 & 0.5 & 4.6 \\
\hline 6 & 46 & 0.26 & 0.021 & 91.8 & 87 & 5.3 & 0.5 & 0.5 & 10.4 \\
\hline 7 & 34 & 0.74 & 0.021 & 88 & 85.7 & 2.7 & 1.0 & 1.0 & 2.1 \\
\hline 8 & 46 & 0.74 & 0.021 & 90.7 & 90 & 0.7 & 1.5 & 1.3 & 9.9 \\
\hline 9 & 30 & 0.5 & 0.015 & 93.7 & 94.1 & 0.4 & 1.1 & 1.0 & 8.2 \\
\hline 10 & 50 & 0.5 & 0.015 & 89.4 & 97.5 & 9.1 & 0.9 & 1.1 & 19.1 \\
\hline 11 & 40 & 0.1 & 0.015 & 86.6 & 89.9 & 3.8 & 0.2 & 0.1 & 18.7 \\
\hline 12 & 40 & 0.9 & 0.015 & 29.1 & 34.2 & 17.6 & 0.4 & 0.6 & 27.8 \\
\hline 13 & 40 & 0.5 & 0.005 & 19.2 & 27.8 & 44.9 & 0.2 & 0.2 & 6.8 \\
\hline 14 & 40 & 0.5 & 0.025 & 88.9 & 88.7 & 0.2 & 0.7 & 0.8 & 13.0 \\
\hline 15 & 40 & 0.5 & 0.015 & 89.1 & 88.5 & 0.6 & 0.7 & 0.7 & 1.1 \\
\hline 16 & 40 & 0.5 & 0.015 & 88.9 & 88.5 & 0.4 & 0.7 & 0.7 & 0.9 \\
\hline 17 & 40 & 0.5 & 0.015 & 89.1 & 88.5 & 0.6 & 0.7 & 0.7 & 1.1 \\
\hline 18 & 40 & 0.5 & 0.015 & 88.6 & 88.5 & 0.0 & 0.7 & 0.7 & 0.6 \\
\hline
\end{tabular}

$\mathrm{PE}=$ percent esterification $(\%) ; \mathrm{EC}=$ ester concentration $\left(\mathrm{mol} \mathrm{L}^{-1}\right) ; \mathrm{PV}=$ predicted value; $\mathrm{SD}=$ standard deviation $(\%)$.

Table 3. ANOVA for the responses of percent esterification and ester concentration

\begin{tabular}{|c|c|c|c|c|c|c|c|}
\hline \multirow{2}{*}{ Source of variation } & \multicolumn{2}{|c|}{ SS } & \multirow{2}{*}{ DF } & \multicolumn{2}{|c|}{ MS } & \multicolumn{2}{|c|}{$F$-value ${ }^{\text {a }}$} \\
\hline & PE & $\mathrm{EC}$ & & PE & $\mathrm{EC}$ & PE & $\mathrm{EC}$ \\
\hline Regression & 12802.65 & 1.705014 & 9 & 1422.52 & 0.189446 & 30.98 & 11.11 \\
\hline Residual & 367.35 & 0.136434 & 8 & 45.92 & 0.017054 & & \\
\hline Lack of fit & 367.19 & 0.136423 & 5 & & & & \\
\hline Pure error & 0.17 & 0.000011 & 3 & & & & \\
\hline Total & 13170.00 & 1.841448 & 17 & & & & \\
\hline
\end{tabular}

$\mathrm{R}^{2}$ (percent esterification) $=0.972 ; \mathrm{R}^{2}($ ester concentration $)=0.926 ;{ }^{\mathrm{a}} \mathrm{F}(0.95 ; 9 ; 8)=3.39 ; \mathrm{PE}=$ percent esterification; $\mathrm{EC}=$ ester concentration; $\mathrm{SS}$, sum of squares; DF, degrees of freedom; MS = mean square.

responses of esterification and ester concentration. The application of RSM yielded the following regression model, which is an empirical relationship between the response variable and the test variables in real values, where $T, S$ and $\mathrm{E}$ are the temperature, butyric acid concentration and enzyme concentration, respectively.

Percent esterification $(\%)=173.73-6.12 \mathrm{~T}+0.07 \mathrm{~T}^{2}-$ $143.04 \mathrm{~S}-163.66 \mathrm{~S}^{2}+8.54 \mathrm{E}-0.3 \mathrm{E}^{2}+1.94 \mathrm{TS}-$ $0.05 \mathrm{TE}+10.64 \mathrm{SE}$

Ester concentration $\left(\mathrm{mol} \mathrm{L}^{-1}\right)=6.37-0.29 \mathrm{~T}+0.01 \mathrm{~T}^{2}-$ $1.76 \mathrm{~S}-2.28 \mathrm{~S}^{2}+0.01 \mathrm{E}-0.09 \mathrm{E}^{2}+0.06 \mathrm{TS}+0.01 \mathrm{TE}+$ $0.14 \mathrm{SE}$
The sensitivity of the esterification conditions to enzyme concentration, butyric acid concentration and temperature can be studied from these response surfaces. The best way to predict the relationships between the responses, parameters and their interactions is to analyze the contour plots generated from the predicted model. ${ }^{23}$ Each contour curve represented an infinite number of combinations of two test variables, while the other one remained at its respective zero-level.

From the analysis of the response surfaces and contour plots for the percent of esterification it appears that an increase in the butyric acid concentration decreases the percent esterification at any point in the temperature range studied, and the greatest percent esterification occurred at $0.26 \mathrm{~mol} \mathrm{~L}^{-1}$ butyric acid. In general, increments in 
the butyric acid concentration lower the esterification capacity of lipases. This effect has been reported for the biosynthesis of isoamyl acetate isoamyl isovalerate and for short-chain fatty acid ethyl esters in general. ${ }^{6}$ There may be two reasons for the lower conversions reported at higher butyric acid concentration: the accumulation of water during the progress of the reaction, which favours hydrolysis (the reverse reaction) or, more likely, inhibition by the higher acid or alcohol concentrations. It has been asserted that alcohols are terminal inhibitors of lipases and acids, and may cause acidification of the micro-aqueous interface, leading to enzyme inactivation. ${ }^{24,25}$

At a fixed temperature, esterification showed little variation with increased enzyme concentrations, but with $0.021 \mathrm{~g} \mathrm{~mL}^{-1}$ enzyme, a temperature of $30{ }^{\circ} \mathrm{C}$, and the other conditions at the central point, total esterification from the acid substrate could occur. Even an increase in enzyme concentration had no significant effect at the higher temperatures. Hence, the results show the beneficial effect of using room temperature for the esterification reaction, in order to achieve maximum conversions. Krishna et al. ${ }^{26}$ suggested that high temperatures reduced the operational stability of the enzyme. Furthermore, the use of low temperature is beneficial so that the power costs can be reduced and the enzyme stability can be preserved during prolonged operations.

Figure 2a shows the effects of the enzyme and butyric acid concentrations on the percent esterification. It was observed that when the butyric acid concentration was high (+1.68 level), the reaction hardly occurred with a low enzyme concentration, possibly due to enzyme denaturation or substrate inhibition. It has been asserted that acids may cause acidification of the micro-aqueous interface, leading to enzyme inactivation. ${ }^{24,25}$ The highest values for percent esterification were found between 0.15 and $0.6 \mathrm{~mol} \mathrm{~L}^{-1}$ with the enzyme concentration in the range from 0.012 to $0.024 \mathrm{~g} \mathrm{~mL}^{-1}$.

Enzyme concentration is known to be an important variable in esterifications for the synthesis of various fatty acid esters. The positive effect of enzyme concentration on the synthesis of butyric ester is in agreement with the reports of other authors dealing with the production of flavour esters (ethyl hexanoate, isoamyl isovalerate, isoamyl acetate) using microbial lipases. . $2,27,28^{2}$

At a temperature of $30^{\circ} \mathrm{C}$, the highest ester concentrations were found with a butyric acid concentration ranging from 0.3 to $0.7 \mathrm{~mol} \mathrm{~L}^{-1}$ and an enzyme concentration between 0.015 and $0.025 \mathrm{~g} \mathrm{~mL}^{-1}$, respectively. At a temperature of $50{ }^{\circ} \mathrm{C}$, the highest values for ester concentration were found in the range from 0.5 to $0.9 \mathrm{~mol} \mathrm{~L}^{-1}$ with an enzyme concentration from 0.015 to $0.025 \mathrm{~g} \mathrm{~mL}^{-1}$.
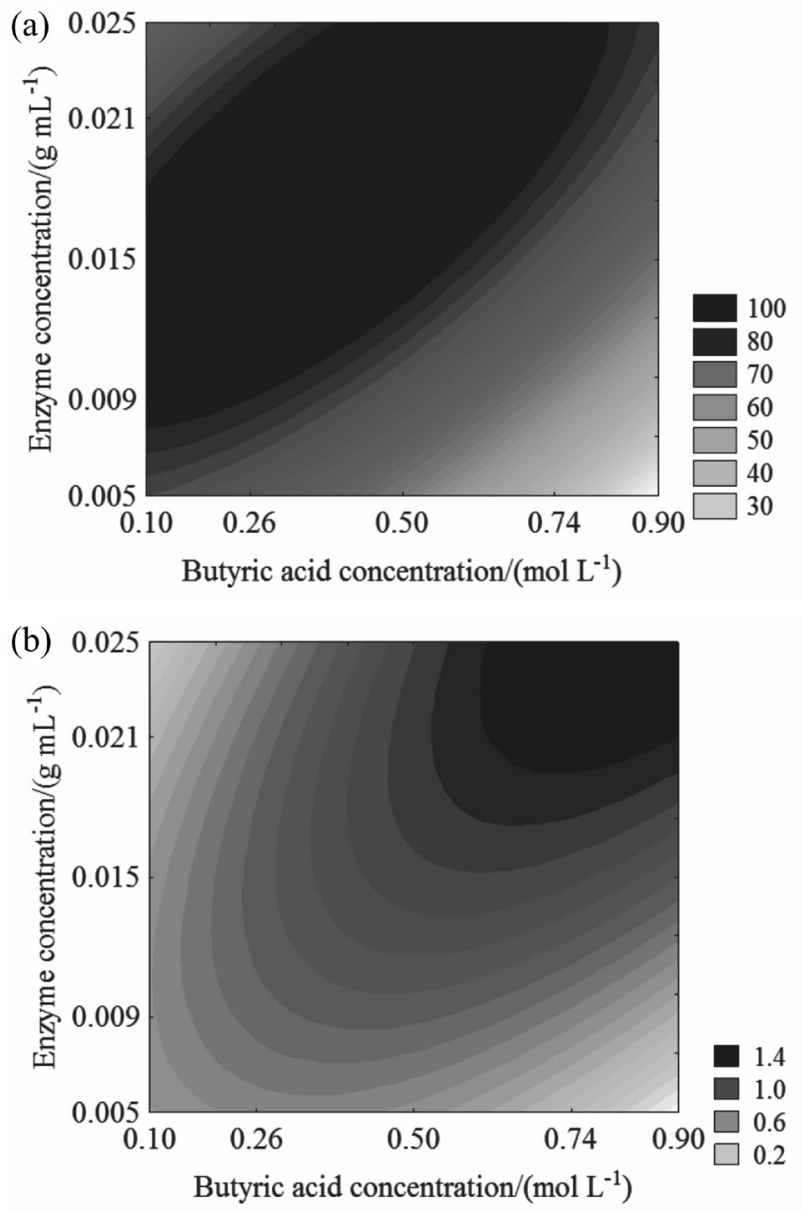

Figure 2. Contour plots from (a) percent esterification (\%) and (b) ester concentration $\left(\mathrm{mol} \mathrm{L}^{-1}\right)$ obtained by equations 4 and 5 , respectively, as a function of enzymatic and butyric acid concentration.

Figure $2 \mathrm{~b}$ shows the contour plot for the isoamyl butyrate concentration as a function of enzyme concentration and butyric acid concentration. The ester concentration was higher at enzyme concentrations above $0.021 \mathrm{~g} \mathrm{~mL}^{-1}$ and butyric acid concentrations between 0.7 and $0.9 \mathrm{~mol} \mathrm{~L}^{-1}$.

Considering the two evaluated responses and the obtained contour plots, the optimized condition was shown to be an enzyme concentration of $0.021 \mathrm{~g} \mathrm{~mL}^{-1}($ level +1$)$, a butyric acid concentration of $0.5 \mathrm{~mol} \mathrm{~L}^{-1}$ (level 0 ), temperature of $30^{\circ} \mathrm{C}$ (level-1.68), alcohol:acid molar ratio of $1: 1$ and shaking rate of $180 \mathrm{rpm}$. Under these optimum conditions the conversion rate was shown to be $92 \%$ and the ester concentration $0.9 \mathrm{~mol} \mathrm{~L}^{-1}$.

Nogales and Contreras, ${ }^{6}$ used response surface methodology to optimize the synthesis of ethyl butyrate in an organic medium ( $n$-heptane) using the immobilized lipase Novozymes 435 . They obtained values for esterification above $70 \%$ with a butyric acid concentration of $0.04 \mathrm{~mol} \mathrm{~L}^{-1}$ and enzyme concentration of $7 \%(\mathrm{~m} / \mathrm{m})$ at $34{ }^{\circ} \mathrm{C}$.

The present results are in good agreement with their investigation. Both investigations gave similar results, 
even though different types of substrate and lipase were employed in the studies.

\section{A comparative study between the optimum conditions for} use with commercial isoamyl alcohol and with isoamyl alcohol from fusel oil

Figure 3a shows the comparison between the results obtained under the optimized conditions using commercial isoamyl alcohol and isoamyl alcohol obtained from the distillation of fusel oil as the substrates. It can be seen in Figure 3 a that the percent esterification was $92 \%$ and $93 \%$ after $18 \mathrm{~h}$, respectively. Figure $3 \mathrm{~b}$ shows the monitoring of the ester concentration, where the use of the optimized conditions and commercial isoamyl alcohol as the substrate resulted in $0.9 \mathrm{~mol} \mathrm{~L}^{-1}$ after $18 \mathrm{~h}$, and isoamyl alcohol from fusel oil as the substrate, $1.0 \mathrm{~mol} \mathrm{~L}^{-1}$. The ANOVA followed by the Tukey Test showed there was no significant difference $(p<0.05)$ between the two isoamyl alcohols with
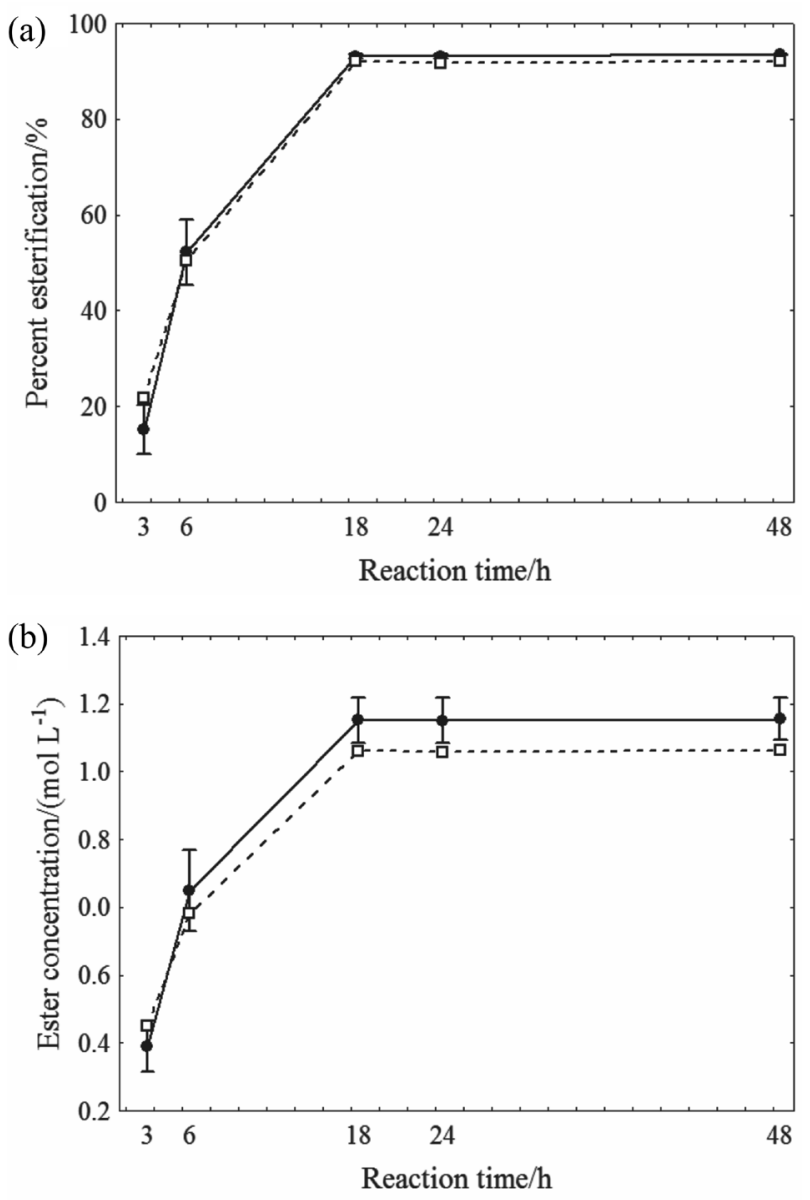

Figure 3. Time course of the synthesis of isoamyl butyrate under the optimized condition using commercial isoamyl alcohol (-•-) and isoamyl alcohol obtained from fusel oil (- $\square-$ ) with respect to the percent esterification (a) and ester concentration (b). The values represent the means of three independent experiments and the error bars indicate the standard deviations. respect to the percent esterification and ester concentration after18 h.

Thus, it was shown there was no significant difference between the optimized conditions using commercial isoamyl alcohol or using that extracted from fusel oil, making the use of this by-product from the alcohol industry a feasible option. If the levels of isoamyl alcohol produced biotechnologically from fusel oil are high enough to make it commercially available, this would be an alternative way of obtaining natural isoamyl butyrate from cheap agricultural residues.

Using the isoamyl alcohol from fusel oil in a solvent free system with the commercial immobilized lipase Novozym 435, Güvenç et al. ${ }^{7}$ enhanced the synthesis of isoamyl acetate by analyzing a second order model using response surface methodology, obtaining the following optimal conditions: acid/alcohol mole ratio of 0.8 enzyme concentration of $12 \%(\mathrm{~m} / \mathrm{m}), 30{ }^{\circ} \mathrm{C}, 150 \mathrm{rpm}$, a reaction system of $6 \mathrm{~mL}$ and $8 \mathrm{~h}$ of synthesis, obtaining a response of $3.8 \mathrm{~mol} \mathrm{~L}^{-1}$ of ester concentration.

Bi et al. ${ }^{29}$ studied the lipase catalyzed production of isoamyl acetate in a solvent of $n$-hexane. The isoamyl alcohol obtained from fusel oil and acetic acid were used as the reactants. The favourable reaction conditions for maximum ester production (92\%) were an enzyme concentration of $9 \%$, an acid:alcohol molar ratio of 1:2 $\mathrm{mol} \mathrm{L}^{-1}$, temperature of $40^{\circ} \mathrm{C}$ and reaction time of $6 \mathrm{~h}$.

The environmental impact of biotechnological utilization of food industry and agricultural wastes and by-products is twofold: the utilization for manufacture of value-added products on the one hand, and the environmentally safe, waste-free biotechnological process using mild conditions on the other. ${ }^{9}$ Owing to its rich alcohol composition and availability in large quantities, fusel oil can be considered an inexpensive source of starting material for the production of important natural flavor compounds. ${ }^{8}$

The enzymatic synthesis of isoamyl butyrate was carried out using Lipozyme TL IM in an organic media. From an evaluation of the effects of the fractional factorial design on the synthesis of isoamyl butyrate, the variable that exerted the greatest influence was the enzyme concentration, followed by the butyric acid concentration and the temperature. Response surface methodology was used to optimize the percent esterification and ester concentration. The optimized condition considering the percent esterification and ester concentration was the following: enzyme concentration of $0.021 \mathrm{~g} \mathrm{~L}^{-1}$, butyric acid concentration of $0.5 \mathrm{~mol} \mathrm{~L}^{-1}$, temperature of $30{ }^{\circ} \mathrm{C}$, alcohol:acid molar ratio of $1: 1$ and shaking rate of $180 \mathrm{rpm}$. By comparing the use of the optimized condition with commercial isoamyl alcohol as the substrate and with that obtained from the distillation of fusel 
oil, the percent esterification after $18 \mathrm{~h}$ was $92 \%$ and $93 \%$, respectively, and the ester concentration was 0.9 mol L-1 and $1.0 \mathrm{~mol} \mathrm{~L}^{-1}$. As a result, it can be said that the fusel oil generated as a by-product during the production of alcohol can be recycled by a green chemical process such as the one used in this study.

\section{References}

1. Santos, J. C.; Castro, H. F.; World J. Microbiol. Biotechnol. 2006, 22, 1007.

2. Romero, M. D.; Calvo, L.; Alba, C.; Daneshfar, A.; J. Biotechnol. 2007, 127, 269.

3. Šabeder, S.; Habulin, M.; Knez, Ž.; J. Food Eng. 2006, 77, 880.

4. Žnidaršič-Plazl, P.; Plazl, I.; Process Biochem. 2009, 44, 1115.

5. Ahmed, E. H.; Raghavendra, T.; Madamwar, D.; Appl. Biochem. Biotechnol. 2010, 160, 2102.

6. Nogales, J. M. R.; Contreras, E. R. E.; Process Biochem. 2005, 40,63 .

7. Güvenç, A.; Kapucu, N.; Kapucu, H.; Aydoğan, Ö.; Mehmetoğlu, Ü.; Enzyme Microb. Technol. 2007, 40, 778.

8. Castro, H. F.; Moriya, R. Y.; Oliveira, P. C.; Soares, C. M. F.; Appl. Biochem. Biotechnol. 1999, 77-9, 817.

9. Yilmaztekin, M.; Erten, H.; Cabaroglu, T.; Food Chem. 2009, 112, 290.

10. Dörmo, K.; Bélafi-Bakó, K.; Bartha, L.; Ehrenstein, U.; Gubicza, L.; Biochem. Eng. J. 2004, 21, 229.

11. Aragão, V. C.; Anschau, A.; Porciuncula, B. D. A.; Thiesen, C.; Kalil, S. J.; Burkert, C. A. V.; Burkert, J. F. M.; Quim. Nova 2009, 32, 2268.

12. http://www.anvisa.gov.br/legis/resol/2007/rdc/02_170107rdc.htm accessed in May 2011.

13. Chowdary, G. V.; Prapulla, S. G.; Process Biochem. 2002, 38 , 393.

14. Abbas, H.; Comeau, L.; Enzyme Microb. Technol. 2003, 32, 589.
15. Gomes, F. M.; Paula, A. V.; Silva, G. S.; Castro, H. F.; Quim. Nova 2006, 29, 710.

16. Oliveira, P. C.; Alves, G. M.; Castro, H. F.; Mei, L. H. I.; Quim. Nova 2000, 23, 632.

17. Güvenç, A.; Kapucu, N.; Mehmetoğlu, Ü.; Process Biochem. 2002, 38, 379.

18. Box, G. E. F.; Hunter, W. G.; Hunter, J. S.; Statistics for Experimenters: An Introduction to Design, Wiley: New York, USA, 1978.

19. Burkert, J. F. M.; Maugeri, F.; Rodrigues, M. I.; Biores. Technol. 2004, 91, 77.

20. Talat, M.; Prakash, O.; Hasan, S. H.; Biores. Technol. 2009, $100,4462$.

21. Macedo, G. A.; Pastore, G. M.; Rodrigues, M. I.; Process Biochem. 2004, 39, 687.

22. Rahman, M. B. A.; Chaibakhsh, N.; Basri, M.; Rahman, R. N.Z. R A.; Salleh, A. B.; Radzi, S. M.; J. Chem. Technol. Biotechnol. 2008, 83, 1534.

23. Shih, I.; Hung, S.; Chen, F.; Ju, H.; Shieh, C.; Food Chem. 2007, $100,1223$.

24. Chowdary, G. V.; Ramesh, M. N.; Prapulla, S. G.; Process Biochem. 2000, 36, 331.

25. Laane, C.; Boeren, S.; Vos, K.; Veeger, C.; Biotechnol. Bioeng. 1987, 30, 81 .

26. Krishna, S. H.; Sattur, A. P.; Karanth, N. G.; Process Biochem. 2001, 37, 9.

27. Krishna, S. H.; Manohar, B.; Divakar, S.; Prapulla, S. G.; Karanth, N. G.; Enzyme Microb. Technol. 2000, 26, 131.

28. Xu, Y.; Wang, D.; Mu, X. Q.; Zhao, G. A.; Zhang, K. C.; J. Mol. Catal. B: Enzym. 2002, 18, 29.

29. Bi, F.; Iqbal, S.; Ali, A.; Arman, M.; Mahmood-Ul-Hassan.; J. Chem. Soc. Pak. 2009, 31, 485.

Submitted: January 17, 2011

Published online: September 23, 2011 